\title{
Fenomenologia da religião como essencialista criptoteologia: reconsiderações críticas
}

\author{
Phenomenology of religion as essentialist and criptotheology: critical \\ reconsiderations
}

Frederico Pieper*

\begin{abstract}
Resumo
Este artigo tem por objetivo analisar as críticas que se faz no contexto brasileiro de que a fenomenologia da religião é essencialista e seria espécie de criptoteologia. Essa análise será conduzida a partir da confrontação dessas críticas com as considerações metodológicas de autores que se identificam com a fenomenologia, especialmente os de tradição holandesa. Para tratar dessas temáticas, o artigo se concentra em dois temas. Em primeiro lugar, para abordar a temática do essencialismo, trata da relação entre história e sistema, buscando mostrar até onde ela pode ser considerada como forma de essencialismo. Em segundo lugar, para abordar a temática da criptoteologia, o artigo busca mostrar como esses autores buscam diferenciar fenomenologia e teologia. A intenção final do artigo não é estabelecer uma defesa da fenomenologia, mas indicar a necessidade de um debate mais aprofundando dessas questões no contexto brasileiro, uma vez que essas temáticas se mostram muito mais complexas do que, muitas vezes, as críticas pressupõem.
\end{abstract}

Palavras-Chave: Fenomenologia da Religião; essencialismo; teologia; Ciência da Religião.

\begin{abstract}
This article aims to analyze criticisms that are made in the Brazilian context, accusing phenomenology of religion of being essentialist and a kind of cryptoteology. This analysis will be conducted from the confrontation of these critiques with the methodological considerations that authors who identify themselves with phenomenology, especially those of Dutch tradition. In order to address these issues, the article is divided in two parts. First, in relation to the critique of essentialism, it will focus on the relationship between history and system, trying to demonstrate in what sense it could be considered as essentialist. Secondly, in relation to the critique of criptotheology, the article shows how these authors attempt to differentiate between theology and phenomenology of the religion. The final purpose of the article is not to establish a defense of phenomenology of religion, but to indicate the need for further discussion of these issues in the Brazilian context, since these themes are much more complex than some criticisms presuppose.
\end{abstract}

Keywords: Phenomenology of Religion; essentialism; theology; Religious Studies.

Artigo submetido em 31 de maio de 2019 e aprovado em 28 de agosto de 2019.

* Doutor em Ciências da Religião pela UMESP. Professor da UFJF. País de origem: Brasil. E-mail: fredericopieper@gmail.com 


\section{Introdução}

Em nosso contexto, a ausência de debate mais detido em torno da fenomenologia da religião traz como consequências críticas muito rápidas em relação a ela ou sua defesa apaixonada. Em virtude disso, em ambas as tendências, não se consideram suas nuances internas. No primeiro caso, o problema está em uma redução da extensa produção contribuição da fenomenologia a um ou dois autores, como se os limites desses autores fossem extensivos a toda essa escola. Cria-se um espantalho contra o qual se elaboram pareceres condenatórios - não raras vezes, apressados demais. Isso é, em parte, reflexo da associação que se fez entre Rudolf Otto e fenomenologia da religião. No segundo caso, o nome fenomenologia é utilizado para nomear empreitadas que nada ou muito pouco têm efetivamente de fenomenologia, reduzindo-a ao mero emprego de algumas ferramentas metodológicas.

Ainda que não tenha espaço para tratar de algumas premissas nesse artigo, é importante colocar de onde ele parte. A primeira premissa é a de que Rudolf Otto não é propriamente um fenomenólogo, mas um filósofo da religião ou teólogo. Ele próprio e alguns de seus contemporâneos conceberam $O$ sagrado como uma contribuição teológica para o entendimento do cristianismo. Outro pressuposto importante aponta para a necessidade de se diferenciar fenomenologia da religião e fenomenologia filosófica. Esta foi fundada por Edmund Husserl e conta com seguidores proeminentes no campo filosófico contemporâneo, inclusive com interesses na temática religiosa. Por outro lado, há uma tradição de pensadores mais ligados à Ciência da Religião que se entendem como fenomenólogos (aliás, empregam essa nomenclatura antes de Husserl)1 ${ }^{1}$, cujas ideias não são mera aplicação das noções de Husserl para o entendimento da religião. Essa tradição, muitas das vezes, se desenvolveu sem relação alguma ou com parco contato com a

\footnotetext{
${ }^{1}$ Cabe ressaltar que o termo fenomenologia já era empregado desde a segunda metade do século XVIII, no caso da Alemanha, surge com o correspondente de Kant, Johan Heinrich Lambert, como leis dos fenômenos. Já no contexto inglês, é empregado como descrição e classificação de dados segundo características observáveis (JAMES, 1995, p. 23). Monlendijk (2000, p. 28) defende que a fenomenologia da religião tenha tido início com van der Leeuw, que realmente a colocou no mapa. Antes dele, segundo seu levantamento, há referências esporádicas e pouco desenvolvidas. No entanto, a grande maioria dos autores concorda com a precedência de Chantepie de la Saussaye (SHARPE, 1975, p. 5; BLEEKER, 1963, p. 2; 1975, p. 5; CAPPS, 1995, p. 109; COX, 2006, p. 105).
} 
fenomenologia filosófica. Essas duas premissas foram objeto de análise em outro artigo. Portanto, para avançar a discussão, penso não ser necessário retomar esses temas.

Considerando esse cenário, a intenção desse texto não é estabelecer uma defesa da fenomenologia da religião. Antes, o que pretendo é promover uma discussão mais interna a ela, especialmente verificando até onde alcançam as críticas que a acusam de ser essencialista e espécie de criptoteologia². Para tanto, essas temáticas serão contrastadas com a análise de produções de autores que se reconhecem como fenomenólogos.

Não é minha pretensão tratar dos mais diversos autores e escolas da fenomenologia da religião. Cada um deles mereceria atenção especial a fim de captar o movimento peculiar de cada proposta. Mas, diante da necessidade de se estabelecer um escopo mais bem delimitado, vou privilegiar a escola holandesa, ainda que não me circunscreva apenas a ela. Esse delineamento permite indicar as lacunas decorrentes de críticas muito apressadas a esse importante ramo dos estudos de religião. E ainda, para fins desse artigo, vou privilegiar as partes dos livros desses autores em que se desenvolvem discussões teórico-metodológicas. Portanto, a aplicação desses instrumentais na interpretação da religião, realizada muitas vezes por esses mesmos autores, não está na mira desse artigo.

\section{A fenomenologia da religião como essencialista}

\subsection{Abordagem sistemática e essencialismo}

Não são raros os textos que deferem acusação de que a fenomenologia da religião seria essencialista. Ao não dar o devido valor à história, ao contexto histórico, ao empírico e ao singular, elaborando categorias generalistas como "sagrado", seu alcance e contribuições encontrariam fortes limites, alinhando-se a

\footnotetext{
${ }^{2}$ Em parte, as críticas replicam o que se diz em outros países. Penner (1970, p. 29), por exemplo, acusa a fenomenologia da religião de falta de rigor metodológico e clareza conceitual. Fitzgerald (2000, p. 19-21) a acusa de criptoteologia. E ainda, McCutcheon (2001, p. $\mathrm{XV}$ ) entende que se trata de um nome para pesquisas superficiais. Como alternativa a esse modelo, esses autores defendem aproximação que tendem a defender de abordagens mais próximas das ciências sociais.
} 
posturas que podemos denominar de essencialistas (USARSKI, 2006, p. 36; ENGLER, 2004; GASBARRO, 2013, p. 79; CAMURÇA, 2011, p. 17; SILVEIRA, 2016).

É preciso, de início, reconhecer que, quando é utilizado, há pouco consenso no significado do termo essencialismo ou à crítica que ele enseja. Por vezes, é identificado com qualquer tentativa de elaboração de categorias compreensivas um pouco mais abrangentes e sistemáticas, como se isso por si só significasse abandonar as singularidades das manifestações religiosas. Outra leitura, que me parece mais frutífera, restringe essa designação para racionalidades que buscam enquadrar os fenômenos singulares em categorias compreensivas que se queiram atemporais e universais. Neste o caso, o particular nada mais é do que exemplar de conceitos universais. No entanto, numa perspectiva mais alinhada à hermenêutica filosófica, há outra maneira de se entender essa relação. Há o reconhecimento da necessidade de elaboração de categorias compreensivas mais abrangentes, desde que admitam sua transitoriedade e finitude. Elas não refletem a "realidade", mas são como mapas que nos permitem vislumbrar um território (PIEPER, 2019, p. 27). Portanto, para esta última perspectiva, é possível elaborar categorias mais abrangentes que, desde que reconheçam suas limitações, não poderiam ser classificadas como essencialistas (LEWIS, 2015, p. 43).

A fenomenologia da religião surge com a intenção de superar as abordagens muito particularistas da história da religião, com sua ênfase em um grupo ou tradição religiosa específica. No entanto, isso nos autoriza a inferir que todos os fenomenólogos busquem determinar a essência da religião ou que, por alguma outra razão, possam tão facilmente serem assim julgados por elaborarem conceitos universais?

Parece-me claro que em alguns autores da fenomenologia essa tendência se justifica. É exemplar o texto de Friedrich Heiler sobre a contribuição fundamental da Ciência da Religião como meio de viabilizar o diálogo inter-religioso. O fenomenólogo da religião, na sua famosa preleção, defende que há sete princípios 
de unidade em todas as religiões (HEILER, 1996)3. Ao contrário da ênfase atual na diversidade como caminho de superação da violência, a paz poderia ser alcançada por meio do reconhecimento do que há em comum. Ao se assumir que no fundo as diversas tradições religiosas dizem o mesmo, não haveria motivos para violências mútuas. Para, entretanto, alcançar essa unidade subjacente, as singularidades são ultrapassadas em direção aos elementos compartilhados. Assim, recuperam-se as estruturas essenciais da religião tendo em vista uma finalidade prática do diálogo4.

No entanto, essa não é a única perspectiva sobre o tema no interior da fenomenologia da religião. W. B. Kristensen, em sua obra Meaning of Religion indica que a fenomenologia, enquanto método, tem por objetivo "chegar o mais longe possível em contato com os dados religiosos e compreendê-los como extremamente variados e divergentes, fazendo uso de métodos comparativos" (KRISTENSEN, 1960, p. 11). Dessa maneira, um aspecto constituinte da fenomenologia está em considerar os fatos e dados em sua diversidade. Ao menos em sua perspectiva teórica, Kristensen defende que se pondere sobre esses dados em toda sua amplitude, o que significa atenção também às particularidades por meio da abordagem comparativa. Dessa maneira, a fenomenologia não simplesmente considera os dados, mas busca, por meio da comparação, categorias capazes de organizá-los a fim de captar elementos estruturantes. Um aspecto aqui é importante. Para ele, o empírico é o ponto de partida e o elemento sobre o qual a fenomenologia se debruça, ao mesmo tempo em que busca elaborar categorias que permitam a compreensão dessa massa de informação vinda da pesquisa mais concreta. Esse aspecto confere à fenomenologia da religião vínculo, mas propósito distinto da história da religião. Ou, numa elaboração do próprio autor: "Fenomenologia da Religião é o tratamento sistemático da História da Religião" (KRISTENSEN, 1960, p. 1).

\footnotetext{
${ }^{3}$ 1) A realidade do transcendente, do divino, do sagrado, do Outro, do verdadeiro ser. Por sobre as coisas passageiras, levanta-se o eterno, a ordem, o tao, o rtam, o logos; 2) Essa realidade transcendente é imanente aos corações humanos, visto que o espírito divino vive nas almas dos seres humanos; 3 ) Essa realidade é para o ser humano seu maior bem, a maior verdade, justiça, bondade e beleza. É o summum bonum; 4) Essa realidade do divino é o amor último que se revela aos homens e nos homens; 5) O caminho do homem até Deus é, universalmente, o sacrifício; 6) As religiões não ensinam somente o caminho até Deus, mas também até o próximo. As noções de amor e mesmo de humanidade aparecem em diversas tradições religiosas; 7) $O$ amor é o caminho mais elevado para Deus (HEILER, 1996, p. 178).

${ }^{4}$ No caso de Eliade, no seu projeto de estabelecer uma morfologia do sagrado, percebe-se essa tendência. O subtítulo de sua obra mais conhecida, O sagrado e o profano, é justamente "a essência das religiões" (ELIADE, 1992).
} 
Mas se a fenomenologia da religião se constitui como esse tratamento sistemático da história, por que não denominá-la filosofia? Nesse ponto já nos deparamos com uma distinção entre sistematização e essência. A fenomenologia se situa num termo médio, entre a história e a filosofia. Ela supera as singularidades e particularidades que são objeto de preocupação da história, mas não chega a propor essências, coisa típica da filosofia na acepção de Kristensen. As tipologias que a fenomenologia constrói não devem ser tomadas como essências em sentido filosófico forte. Afinal, as generalizações que as tipologias expressam não possuem o caráter de necessidade ou mesmo de atemporalidade que o conceito tradicional de essência advoga para si. Portanto, a fenomenologia da religião, por meio de tipologias e categorias elaboradas a partir da análise comparativa dos dados e fatos, se situa para além da abordagem de singularidades típica da história das religiões, mas não chega a propor essências, tarefa reservada à filosofia da religião e que pode, inclusive, se desenvolver valendo-se das tipologias.

Não se deve esquecer que a fenomenologia, ao menos para Kristensen, implica em métodos comparativos. E, para ser fazer comparação são necessários conceitos mais abrangentes. Sem eles, a comparação de um sistema religioso com outro não seria possível. Tomemos por exemplo a noção de sacrifício. Como poderia comprar duas práticas rituais em grupos religiosos distintos sem, por exemplo, uma categoria compreensiva como essa capaz de colocá-las em diálogo? Essa proposição de Kristensen é, em certa medida, o desenvolvimento de algumas ideias de seu antecessor. Pierre Daniël Chantepie de la Saussye já alertava que o aspecto sistemático da fenomenologia da religião estaria em classificar e agrupar fenômenos semelhantes. Seu seguidor pensa de maneira parecida, mas com um detalhe: é preciso dar a devida importância às singularidades. $\mathrm{E}$, ao contrário do que se poderia imaginar, as tipologias e as categorias podem auxiliar a encontrar o sentido específico dos fenômenos religiosos e seu lugar no tempo e no espaço, afinal a história não pode operar sem uma ideia. Quem provê essa ideia para o acesso aos dados históricos, permitindo reconhecer suas singularidades são as tipologias e categorias formuladas pela fenomenologia. Nesse processo comparativo, os aspectos mais claros da religião podem auxiliar no entendimento 
daqueles que são mais obscuros, ou em suas palavras, a fenomenologia da religião, "clarifica o sentido do que é pouco conhecido com a ajuda do que é mais bem conhecido" (KRISTENSEN, 1960, p. 268).

Entendimento semelhante é também encontrado em Gerard van der Leeuw. Isso pode causar surpresa, especialmente se consideramos o título dado para sua obra na tradução para o inglês. O título alemão Phänomenologie der Religion (1930) foi traduzido por Religion in Essence and Manifestation. A Study in Phenomenology (1963). No entanto, não nos deixemos levar pelas traduções.

Para Leeuw, a fenomenologia lida com fenômenos. Fenômenos não são “coisas" que aparecem e, então, são experienciadas. Antes, fenômenos surgem da interação entre sujeito e objeto. Portanto, fenômenos não são coisas dadas, mas o aparecer de algo para alguém, ou seja, uma relação de sentido. Nessa direção, a fenomenologia da religião é "o estudo sistemático do que aparece" (LEEUW, 1963 p. 683). Esse sistemático significa reconhecer as os vínculos estruturais que os fenômenos estabelecem entre si, de modo que podem ser articulados segundo algumas "conexões perceptíveis", possibilitando o estabelecimento de tipologias. Essa abordagem tem a ver com a noção heideggeriana de que somente podemos atribuir sentido interpretando e que o mundo é constituído por essa estrutura de remissão de um fenômeno a outro. Essa interpretação implica no reconhecimento de relações entre os fenômenos, de modo que um remete para o outro, permitindo atribuir certa estrutura ao que é inicialmente caótico. Esse movimento é, antes de tudo, uma tentativa de compreender. Portanto, essas conexões e tipologias não precisam ocorrer em todo lugar da história, nem são um retrato da realidade, mas categorias que nos permitem organizar a realidade. Portanto, seu estudo é sistemático no sentido que pretende explorar os principais tipos que aparecem na religião (LEEUW, 1963, p. 596).

O próprio van der Leeuw, apesar da categoria de poder, dá indícios de que não pretende estabelecer uma natureza para a religião. Segundo ele, "ao abordar as 
'grandes' formas entre as religiões, e preparado pela consideração de sua dinâmica, nós nos tornamos cada vez mais cientes que elas não podem ser caracterizadas por um único termo" (LEEUW, 1963, p. 618). Portanto, a complexidade dos fenômenos religiosos, mesmo que se possa encontrar alguma sistematização para ela, não se deixa reduzir a um termo comum.

Essa articulação entre fenomenologia e história perdura no decorrer do desenvolvimento da fenomenologia da religião. Em alguns momentos, a crítica de que a dimensão histórica acabou sendo preterida tem sua razão de ser, especialmente em abordagens com viés mais psicológico. Tanto é assim que na segunda metade do século XX, J. Bleeker assumiu como tarefa pensar essa relação com a dimensão histórica e concreta. É curioso que encontramos formulação bastante parecida com a de Kristensen nos preparativos para um congresso da International Association of History of Religions (IAHR) cujo tema era justamente metodologias da Ciência da Religião. Ao discutir essa relação entre história e fenomenologia da religião, Bleeker afirma: "Fenomenologia da religião é totalmente dependente do material que a história da religião oferece a ela. Por outro lado, a fenomenologia da religião oferece os princípios heurísticos que ajudam os historiadores da religião a encontrar alguma pista para problemas difíceis" (BLEEKER, 1979, p. 176). Ao invés de oposição ou exclusão, Bleeker entende que há mútua dependência entre elas. Uma vez que a história lida com religiões particulares em sua singularidade, ela oferece dados sobre os quais a fenomenologia se debruça para tentar desvendar estruturas constituintes da religião. Por outro lado, essas estruturas também têm importante papel, uma vez que proporcionam uma moldura a partir de onde o historiador pode interpelar o seu objeto mais particular. Portanto trata-se de uma relação circular, na qual uma abordagem ilumina a outra. Por fim, para não me estender ainda mais, essa mesma perspectiva é reafirmada por outro representante da fenomenologia. Logo no início do seu clássico, Fenomenologia da religião, Geo Windegren diz: 
Enquanto a fenomenologia lida com todas as expressões da vida religiosa, onde quer que apareçam, a história da religião investiga, com seu método puramente histórico, o desenvolvimento de religiões individuais. A fenomenologia da religião se esforça para dar uma exposição global de todos os aspectos mutáveis da religião, tornando-se assim o complemento sistemático da história da religião. Esta nos oferece a análise histórica, enquanto que a fenomenologia nos proporciona a síntese sistemática (...) com frequência, os resultados dos trabalhos sistemáticos e históricos se complementam mutuamente. (WINDEGREN, 1969, p. 1).

Para ele, a fenomenologia seria esse momento sistemático a partir dos dados que a história da religião oferece, não havendo oposição entre as duas disciplinas, mas complementariedade. De modo mais incisivo que outros autores, Windegren reconhece que as fronteiras podem ser estabelecidas com clareza na teoria. Já na prática, elas são bem mais porosas, com um campo se entrelaçando no outro, numa espécie de espiral. Talvez, por isso mesmo, Windegren levante tantas suspeitas com relação a abordagens que perdem a base empírica e histórica em vôos imaginativos. Para ele, a sistematização não implica em prescindir do histórico. Pelo contrário. Ela somente faz sentido quando se atém a esse embasamento empírico.

Desse modo, o estabelecimento de teorias mais abrangentes da religião não significa desconsiderar as situações históricas concretas. Por isso mesmo, a fenomenologia da religião anda sobre duas pernas. De um lado, deseja conhecer as situações históricas concretas, mas de outro deve ousar elaborar tipologias e classificações. De um lado, considera os fatos brutos. No entanto, se o estudioso da religião fica apenas nessa dimensão, ele ainda não capta seu objeto próprio. Os fatos interessam. Mas, interessam enquanto imbuídos de significado. Permanecer restrito aos dados e fatos não é fazer justiça ao fenômeno religioso como tal, mas apenas ficar preso à sua mera descrição. Portanto, há a necessidade de se ir além, em busca de seu significado religioso e de suas estruturas. Para não pender nem para um lado nem para o outro é que se deve conduzir uma sistematização. Nesse sentido, é que a história, se de um lado é a base para a fenomenologia, precisa ser suplementada por ela com a sistematização e reflexão sobre os dados factuais. 
Aqui, cabe considerar um argumento. Muitas vezes, avalia-se que essa sobrevalorização da estrutura e das tipologias levaria a fenomenologia a desconsiderar as particularidades históricas. No entanto, como fica a posição contrária? Em que medida o elogio do particular, que acaba incorrendo num descritivismo, não pode ser também acusado de supressão da história? Afinal, essa fragmentação exacerbada via a especialização em um campo muito específico de uma religião particular também não representa, no limite, a anulação da história? O fragmento não se torna num ponto isolado, sem relação com outras partes? Não se torna um momento descolado de uma antes e um depois? É claro que não há fenômeno religioso fora da história, de determinantes culturais, sociais, psicológicas etc. Mas, como fica a dimensão histórica diante de uma fragmentação exacerbada? É precisamente por essa razão que esses autores propõem que a fenomenologia da religião seja aplicada conjuntamente com a história da religião. A história pode nos dar fatos e conhecimentos específicos. Mas, como interpretar esse específico senão a partir de noções um pouco mais abrangentes? Não nos deparamos aqui novamente com essa articulação entre fenomenologia e história da religião?

Portanto, na fenomenologia a atenção ao histórico-concreto se mostra de modo articulado com o particular, de modo que a sentença de que a fenomenologia nega a dimensão histórica dos fenômenos não pode ser feita de modo tão imediato. Vejo que essa denúncia pode se sustentar caso consiga se demonstrar que esses autores, não obstante chamarem a atenção para o histórico em suas considerações metodológicas, no momento de aplicar essa teoria na abordagem da religião, acabam pendendo para o tipológico e o estrutural, anulando o histórico. Mas, a meu ver, de início, percebe-se que há uma proposta de articulação entre história e fenomenologia que é um pouco mais complexa do que a crítica deixa entrever. $\mathrm{Na}$ verdade, a estrutura não visa anular a história, mas oferecer categorias para que o específico e o singular sejam valorizados em sua particularidade. 
Outro aspecto a ser enfatizado é o lugar da fenomenologia no âmbito da Ciência da Religião. Por seu caráter sistemático, ela se insere num ponto intermediário entre a história e seu olhar para as singularidades das religiões e a filosofia com sua abordagem mais geral. Esse entre lugar é mais importante do que aparenta. Há poucos consensos na Ciência da Religião quanto a questões de método, objeto, etc. Mas, se há um elemento que é reconhecido pelas mais variadas escolas, autores e tendências é que ela possui duas subdivisões, ainda que os diversos autores nomeiem essas duas subáreas de maneira diferente, bem como também divirjam no modo como elas se relacionam e interagem (MÜLLER, 1893, p. 74; TIELE, 1897, p. 08; 302; KRISTENSEN, 1960, p. 7; KITAGAWA, 1996, p. 40; ELIADE, 1996, p. 123; WACH, 1988, p. 12; GRESCHAT, 2006). A primeira se ocupa de abordagens empíricas da religião, tratando das tradições em suas especificidades. A outra subárea faz abordagem sistemática e teórica da religião. Mas, de todo modo, é interessante observar que os fenomenólogos entendem que a fenomenologia, por seu lugar intermediário, é capaz de articular essas duas subáreas. Aliás, é exatamente por isso que no século XX certas tendências atribuíram a ela um lugar proeminente no âmbito da Ciência da Religião. Para que a Ciência da Religião não se fragmente entre empírico e sistemático, sem nenhuma articulação, a fenomenologia teria o papel de estabelecer vínculos entre elas. Nas palavras de Leeuw, a fenomenologia é capaz de criar "uma ponte entre as ciências especiais preocupadas com a história da religião e a contemplação filosófica" (LEEUW, 1963, p. 687)5.

\subsection{A fundamentação da autonomia da religião e essencialismo}

Uma vez que no Brasil observa-se a tendência de tomar o pensamento de Rudolf Otto como paradigma para a crítica à fenomenologia da religião, essa acusação de essencialismo ganha força pelo modo como Otto fundamenta a religião. Como era corrente no ambiente intelectual da Alemanha do início do

\footnotetext{
${ }^{5}$ Kristensen (1960, p. 9), na mesma direção, afirma: “O lugar que as pesquisa da Fenomenologia ocupa entre a história e a filosofia faz dela extraordinariamente interessante e importante. O particular e o universal se interpenetram de novo e de novo. Fenomenologia é ao mesmo tempo sistemática da história da religião e filosofia da religião aplicada".
} 
século XX, ele busca encontrar alguma categoria a priori para assentar a religião. Esse recurso kantiano tem como finalidade encontrar uma fundamentação "pura” para o religioso que esteja na própria constituição da razão e, portanto, para além das instabilidades do histórico e do empírico. Otto, inspirando por Kant, não faz nada de diferente de muitos de seus contemporâneos. No entanto, esse amparo da religião na subjetividade é fortemente combatido pela virada linguística e hermenêutica do século XX, tornando-se hoje em dia bastante problemático, especialmente na reivindicação de seu caráter universal, necessário e atemporal.

No entanto, essa desconfiança não ocorre somente nos dias de hoje. Ela já estava presente entre os teóricos que se entendem como fenomenólogos da religião. Nessa direção, W. B. Kristensen, numa parte em que examina a noção de sagrado, entende que o tratamento de Otto representa um estudo em Filosofia da Religião/Teologia Sistemática que é,

\begin{abstract}
na verdade, de natureza bastante teórica e pertence propriamente ao campo da Filosofia da Religião, que busca determinar a essência da religião em geral. Mas é crucial para o resto da exposição que Otto, o filósofo e o teólogo sistemático, não veja que, com base nisso, nenhuma tradução seja possível para o entendimento histórico que ele estabelece como seu objetivo. (KRISTENSEN, 1960, p. 16).
\end{abstract}

Em termos concisos, o problema da noção de sagrado está na relação entre essência e história, que se mostra na dissonância entre a fundamentação num $a$ priori e o empírico, decorrente de seu método dedutivo. É importante destacar o lugar dessa crítica. Se observarmos bem, temos aqui um fenomenólogo da religião, W. Brede Kristensen, fazendo uma crítica à noção de sagrado de Otto. Steven Engler (2004), por exemplo, ao apontar alguns debates no contexto norteamericano, ressalta aspectos muito parecidos, especialmente com relação à noção de sagrado. Aliás, muitas das críticas que se fazem a R. Otto ou à noção de sagrado no Brasil, como se fossem prontamente extensivas à fenomenologia, já podem ser encontradas em autores que se autodenominavam fenomenólogos da religião, como ilustra bem o trecho acima. Portanto, se essa observação já é encampada por

\footnotetext{
${ }^{6}$ Waardenburg (2000, p. 264), por exemplo, ressalta os interesses claramente teológicos da escola de Marburgo, especialmente quando contrastados com os interesses de W. B. Kristensen.
} 
fenomenólogos da religião, como fica a crítica que se faz à fenomenologia por se ancorar numa noção vaga de sagrado e, em virtude disso, não dar atenção ao empírico, ao contexto social, ao particular?

Ainda na proposta de Kristensen, partir do empírico para compreender a religião significa abordá-la como vivida. Apontar os significados das vivências religiosas é encontrar a relevância que elas têm para os religiosos, para o fiel7. Isso, no entanto, não significa que se deva restringir à perspectiva do religioso. Parte-se desse ângulo inicial para, a partir dele, formular categorias compreensivas. Portanto, nesse caso, não há recurso a alguma fundamentação transcendental que possibilitasse alinhar as religiões. Antes, o caminho é o inverso. Ao analisar as religiões do ponto de vista dos seus praticantes, sem impor teorias ou esquemas prévios a elas (o recado era para os evolucionistas, incluso Tiele, seu antecessor em Leiden), o estudioso da religião pode elaborar suas análises. Esse exercício de simpatia [Einfüllen], ainda que necessário, não significa uma identificação total com o religioso. Em seus próprios termos:

Toda religião busca ser compreendida do seu próprio ponto de vista, isto é como ela é compreendida por parte de seus fieis [...]. Mas o historiador não pode compreender o caráter absoluto dos dados religiosos do mesmo modo que o crente os compreende. Há uma distância entre ele e o objeto de pesquisa, pois não pode se identificar com o objeto como o crente faz. (KRISTENSEN, 1971, p. 7).

É importante observar que Kristensen estudava religiões antigas, sobretudo a dos egípcios. Portanto, esse exercício de simpatia era pensado em relação a culturas e povos muito distantes historicamente. Por isso mesmo, suspeita de que a racionalidade moderna e a moldura do cristianismo representam um empecilho para se entender a religião dos antigos em sua própria perspectiva. A simpatia exige esforço e imaginação, mas sempre esbarra em certas limitações intransponíveis.

\footnotetext{
${ }^{7}$ Por isso mesmo, John Carman (2000, p. 172) afirma: “Eu gostaria apenas de notar (...) que Kristensen considerou a imaginação religiosa o coração da pesquisa acadêmica, sem a qual ele é um simples colecionador de fatos".
} 
Em J. Bleeker, encontramos olhar parecido, no entanto com ênfase sobre outro aspecto: a autonomia da religião. Para que se compreenda bem o que está em jogo aqui é importante uma distinção inicial. Há uma preocupação por parte da fenomenologia em entender a religião em sua autonomia. Aliás, é nesse sentido que se deve entender quando se diz que ela evita "compreensões reducionistas". Essa expressão, ao contrário do que indica Emerson Silveira (2016, p. 86), não exclui o reconhecimento de que todo empreendimento científico é uma redução. Aliás, a ciência moderna é mobilizada justamente pela tentativa de encontrar leis e padrões mais simples possíveis e capazes de explicar a maior amplitude de fenômenos. Ou seja, a ciência busca justamente reduzir a complexidade de fenômenos a leis e princípios. Isso é válido também para as abordagens científicas da religião.

O alerta diz respeito a outro tipo de reducionismo. Ele se refere às abordagens da religião que a buscam explicá-la a partir de elementos não religiosos (cf. INDINOPULOS; YONAN, 1994). Nesse caso, a religião é reduzida a outro fator que não é da ordem do religioso: à economia, à política, à psique, etc. Portanto, nessa perspectiva chamada de reducionista, o que está em jogo na religião é fundamentalmente sempre outra coisa que é não religiosa. Se há uma ideia bastante recorrente na fenomenologia é justamente a tentativa de compreender a religião a partir de si mesma. Isso quer dizer que há o empenho em interpretar a religião a partir de contornos religiosos próprios, ao invés de sempre explicá-la a partir de fatores de outra ordem. Não se trata de negar o que a religião tem de cultural, econômico, político, psicológico, etc. Mas, de captar os aspectos que fazem com que um fenômeno seja também "religioso". Para empregar um termo de Eliade, é entender a religião em escala religiosa (ELIADE, 2008, p. 01).

Novamente, no contexto brasileiro, a crítica acaba sendo cativa dessa rápida identificação da fenomenologia com o pensamento de Otto. Para ele, é evidente essa tentativa de entender a religião a partir de seus próprios termos. A todo o momento em $O$ sagrado, observamos Otto dizendo que a religião não é moral, mas tem valor por si mesma, sendo um "sentimento" de natureza distinta e peculiar. E, novamente, a fundamentação transcendental tem por objetivo garantir essa 
especificidade da religião (Cf. PIEPER, 2018). Portanto, se reduzimos a fenomenologia ao pensamento de Otto, parece que sua defesa da autonomia da religião via fundamentação transcendental justifica a acusação de essencialismo. Mas, isso não é aceito por outros fenomenólogos. Se Bleeker concorda com a autonomia da religião, ele não assente com esse modelo transcendental de justificação. Para ele,

O objetivo das duas disciplinas em jogo [Fenomenologia e história da religião] não pode ser outro senão a descrição e a compreensão da religião como um fenômeno humano com uma dimensão mais profunda [...]. Portanto, deve ser claramente indicado que a pesquisa histórico-religiosa não tem como objetivo principal compreender o homem religioso como tal, mas deve ter a ambição de esclarecer como o homem encontra sua atitude em relação à realidade divina. A religião não é, em primeiro lugar, a tentativa do homem de se integrar à sociedade, mas é o esforço para manter sua posição contra as esmagadoras forças cósmicas que influenciam a vida humana, tanto individual quanto colectivamente. (BLEEKER, 1979, p. 175).

Esse trecho traz grande contribuição para o tema em discussão. Bleeker pontua que não se trata de estudar o homo religiosus (ou a consciência religiosa), mas essa atitude do ser humano frente à realidade essencial. Aqui não temos somente de detalhe de redação, mas há um fator significativo. A formulação consciência religiosa poderia transmitir uma noção mais estática ou de que há uma faculdade humana do divino ou a religião como um dado constituinte do ser humano. Ao destacar que se trata de uma atitude, penso que se certifica dinâmica a essa relação, podendo ressaltar com mais clareza sua dimensão histórica. Portanto, não é um fator que constitui o ser humano, mas é uma atitude decorrente do encontro do ser humano com forças que ele reconhece como superiores.

Mas, declarar a religião como histórica e social não significa reduzi-la a fatores não-religiosos. Em outros termos, é possível se aproximar dessa atitude dinâmica do ser humano em escala religiosa sem abdicar das múltiplas relações que estabelece com as outras esferas sociais (economia, política, psique etc.). Isso implica em, por exemplo, reconhecer que a finalidade mais importante da religião em sua autonomia não é a integração do indivíduo na sociedade, mas essa relação com o divino. A perspectiva de que religião tem como fator importante a relação do 
humano com o sentido (com totalidades maiores que ele, como cosmos, deuses, ancestrais etc.) não exclui que essa atitude tenha consequências e relação importantes com a manutenção da coesão social, por exemplo. No entanto, não se deveria reduzir a religião a isso, como se esse fosse seu fim último.

O interessante na postura de Bleeker no abandono dessa atitude transcendental é afirmar a autonomia da religião como um axioma (PALS, 1987). Portanto, não se trata de encontrar uma fundamentação segura e necessária na subjetividade humana, mas é um pressuposto do qual o pesquisador parte. Assim como outro estudioso pressupõe que a religião é um fenômeno econômico, que se insere nos complexos ideológicos e econômicos (GASBARRO, 2013, p. 77), é plausível também pressupor que a religião é um fenômeno religioso. Trata-se, portanto, de verificar em que medida e onde essas premissas nos auxiliam ou limitam na abordagem dos fenômenos religiosos.

Ademais, há um argumento bastante simples, mas que deve ser considerado. Ao desenvolver uma pesquisa, sempre partimos de concepções prévias. Até mesmo para que eu possa dizer que uma igreja é um fenômeno religioso, eu já pressuponho uma compreensão do que constitui aspectos peculiares à religião e que me possibilitam dizer que determinado grupo pode ser classificado como um grupo religioso. Sem essa compreensão prévia sequer posso distinguir um grupo como religioso e outro como político, por exemplo. É justamente por entender que a religião abrange certas características específicas que posso delimitar certos grupos, instituições, objetos, comportamentos etc. e classificá-los como religiosos. Portanto, a aposta de Bleeker é que o cientista da religião parta do princípio de que a religião é um fenômeno com autonomia própria.

O termo autonomia não foi escolhido por nós aletoriamente. Pela citação acima, percebe-se que não se trata de conceber a religião como independente da economia, da política, da cultura, etc. Como fenômeno humano, ela se articula com essas dimensões. Autonomia significa que ela tem contornos peculiares que, inclusive, nos permitem estabelecer algum nível de distinção desse fenômeno de 
outros. Se classifico uma igreja como instituição religiosa e um partido como expressão da política, isso é possível porque reconheço na igreja traços que me permitem conferir a ela a qualidade de religião e, no partido, traços do que considero ser o político. Ou seja, para que eu possa delimitar um objeto empírico ou um campo de estudos já devo dispor de antemão de conceitos prévios.

Aonde essa discussão nos conduz? No aspecto do caráter específico da religião, ao se partir de um axioma (particularmente, prefiro a expressão “concepção prévia" - retirada da hermenêutica filosófica) e não mais de uma fundamentação na constituição humana, ainda pode-se, nesse sentido, falar em essencialismo? No caso de Bleeker e outros fenomenólogos, os pressupostos não têm a peremptoriedade de uma fundamentação a priori, mas tem o potencial de se revisar por se reconhecerem finitas. Até mesmo porque a fenomenologia busca elaborar tipologias, deixando o reino das essências para o discurso filosófico.

\section{Fenomenologia da religião como criptoteologia}

Ao lado de essencialismo, outra crítica que pesa sobre a fenomenologia é a de ser uma espécie de discurso teológico que não tem coragem de se apresentar como tal. É como se por detrás de uma terminologia aparentemente "neutra" estariam em operação categorias cristãs, portanto, tratar-se-ia de uma criptoteologia. Tópicos importantes nessa temática são a compreensão de teologia e a insistência dos fenomenólogos, ao menos no plano metodológico, em distinguir o objeto e o método de sua área de pesquisa em relação à teologia.

Chantepie de la Saussaye demarca claramente o lugar da fenomenologia frente à teologia ${ }^{8}$ Por isso mesmo, em seu texto, promove ampliação do objeto da fenomenologia ao empregar dados retirados de diversas tradições religiosas, tais como material bíblico, Oriente próximo, fontes chinesas e indianas, mitologia europeia, antiguidade clássica, informações de Heródoto, Plínio, Tácito, Cícero etc.

\footnotetext{
${ }^{8}$ Teologia e Ciência da Religião "devem seguir, entretanto, caminhos separados e devem ter em vista objetos separado" (CHANTEPIE DE LA SAUSSAYE, 1891, p. 10).
} 
Além desse alargamento, ele também evita temas que poderiam conduzir a temáticas mais especificamente teológicas. Uma vez que seu entendimento de teologia é o discurso que se submete à autoridade de uma revelação, em termos práticos ele evita referências a aspectos da religião que se relacionem com a ideia de revelação. Para ele, não tratar de temáticas dessa natureza seria o suficiente para distinguir fenomenologia e teologia.

No entanto, como simplesmente ignorar dimensões importantes da religião? O medo de se confundir com o discurso teológico por meio da suspensão de certos temas não faz com que o objeto religião fique comprometido? Em outros termos, como simplesmente não tratar da percepção que o religioso tem de que uma montanha, por exemplo, tem um caráter revelatório? E uma pergunta ainda mais difícil, como considerar essa dimensão sem incorrer num discurso teológico e, ao mesmo tempo, sem render-se a reducionismos? De certa maneira, a fenomenologia encontra uma solução engenhosa e fundamental para o estudo científico da religião: não cabe emitir juízos sobre a verdade do objeto da religião.

Desses autores clássicos da fenomenologia, van der Leeuw procura responder a essa questão de modo incisivo. Ele entende que a religião é composta duas dimensões: uma vertical e outra horizontal. No primeiro caso, o fenômeno religioso é entendido como revelação de Deus, que tem consequências para a sociedade e a cultura, mas não é reconhecido como um fenômeno humano propriamente dito. Já no plano vertical, articulam-se as respostas humanas a essa experiência revelatória. Nessa dupla dimensão da religião é que se articulam teologia e fenomenologia. A teologia se ocupa primordialmente com a dimensão vertical, tratando de temas como Deus, revelação e fé, reconhecendo a autoridade de uma revelação. Já a fenomenologia se restringe ao aspecto vertical da religião, de modo que não se constitui propriamente como seu objeto temas como Deus, a revelação ou mesmo a fé. Ela somente tem acesso ao testemunho das pessoas sobre essa revelação, analisando como ela determina seus comportamentos e atitudes (LEEUW, 1963, p. 538; 679). Em outros termos, não trata diretamente desses 
temas, como as pessoas tematizam essas questões. Há aqui, portanto, mediações que precisam ser consideradas.

O aparecer dos fenômenos com os quais a fenomenologia se ocupa de modo nenhum pode ser equiparado com a ideia de revelação presente nas religiões. Enquanto a revelação é, do ponto de vista teológico, espécie de automanifestação do divino, o aparecer do fenômeno é resultado da relação entre sujeito e objeto. Não se considera neste caso a dimensão vertical, mas apenas aquilo que ela tem humano (LEEUW, 1963, p. 565; 649; 661; 699). Portanto, “O fenomenólogo somente pode discutir o que é relatado a ele; ele pode ouvir dos sons autênticos e descrever os objetos em que, segundo as declarações do próprio fiel, a revelação foi para ele efetuada" (LEEUW, 1963, p. 566).

É importante estar atento às mediações que se estabelecem no acesso ao fenômeno religioso, afinal elas são de várias ordens. Assim, a fenomenologia não estuda Deus ou a revelação, nem mesmo a fé como tal, uma vez que, "a fé, por si mesmo e como tal não 'aparece' nem se torna visível” (LEEUW, 1963, p. 538). Ela estuda aquilo que aparece dessa fé por meio da tematização dada pelas pessoas ou pelo modo como ela determina o proceder dos indivíduos e/ou grupos. O que aparece é a interpretação e o testemunho que os religiosos dão a respeito dela. Portanto, no limite, o que a fenomenologia acessa é um discurso sobre essas dimensões teológicas da religião.

Para evidenciar como esse aspecto permeia a fenomenologia, é válido citar Ninian Smart. Já mais ao final do século XX, recoloca essa questão denominando-a de agnosticismo metodológico. Smart defende que o estudioso não deve emitir juízo sobre a realidade daquilo que as comunidades religiosas acreditam, devendo evitar qualquer indagação a respeito de seu valor e verdade. Ele é cauteloso no emprego dessa expressão justamente para evitar compreensões equivocadas. Não se trata de falar de um ateísmo metodológico, como propõe o sociólogo Peter Berger. Afinal, ao utilizar essa expressão já se emite juízo, como se o objeto da crença fosse uma ilusão ou projeção. Para ele, é preciso atribuir amplitude a essa 
suspensão do juízo: o fenomenólogo se abstém completamente de estabelecer qualquer tipo de julgamento, seja de confrontação ou conformação, sobre essa dimensão da religião. Ele afirma: "nós não afirmamos e nem negamos a existência dos deuses" (SMART, 1973, p. 54). Com isso, não é sua intenção pressupor e mostrar a falsidade ou confirmar a realidade do objeto da fé religiosa. Se, por exemplo, Deus existe ou não, isso não faz diferença alguma para a fenomenologia, afinal, ela não está interessada nisso. O que interessa é como os seres humanos tematizam sua experiência significativamente e articulam dimensões de sua vida a partir ou em relação a ela.

Curioso é que nem esse recorte, que intenciona justamente distinguir o objeto da fenomenologia e da teologia, tenha passado incólume à crítica. Sobre isso, num artigo em que explora as tendências do estudo da religião nos Estados Unidos no início da década de 1960, William Oxtoby afirma:

\begin{abstract}
Fenomenólogos, ao conferirem aprovação de princípio para a fé dos outros, preservam isso também para sua própria tradição. A academia está livre de contradizer o evangelismo. A principal clientela potencial da fenomenologia está entre as pessoas religiosamente comprometidas com uma apreciação pelo compromisso religioso [...]. O pesquisador individual entra em uma extensão reverente de conhecimento que fortalece suas próprias atitudes privadas ou compartilhadas em direção a uma realidade transcendente. Na fenomenologia, a ciência das religiões se tornou, com efeito, um exercício religioso em si. (OXTOBY, 1968, p. 598-599).
\end{abstract}

O mais importante desse trecho não é o que ele diz, mas o que pressupõe. Aliás, esse pressuposto é compartilhado por outros autores mais contemporâneos, dentre eles Donald Wiebe. A sua preocupação é que essa suspensão do juízo associada à postura de empatia poderia conduzir à falta de crítica. Em parte, ele tem razão nesse ponto. Há certo risco (!) em se perder a dimensão mais crítica. Mas, o problema é achar que a fenomenologia somente poderia ser crítica ao abordar a verdade do objeto da crença religiosa. Há outras formas pelas quais essa crítica é feita, afinal a fenomenologia busca criar categorias de compreensão da religião e não somente uma mera reprodução do ponto de vista do fiel. Mas, o pressuposto principal da crítica está em entender que a suspensão do juízo significa chancelar a crença do religioso. Em Religião e verdade (1998), o objetivo central de 
D. Wiebe é questionar justamente esse requisito dos estudos de religião. Segundo ele, não se pode esquivar de se questionar a verdade do objeto. A partir disso, inclusive em produções posteriores, ele sempre interpreta o colocar em parêntesis como defesa da existência do objeto da religião. No entanto, não me parece que se deva interpretar as coisas tão dicotomicamente assim. O ponto é mais simples: a fenomenologia, para não se confundir com a teologia, faz um recorte no seu objeto. Não se trata de questionar a verdade do objeto da religião, mas como uma dita experiência é tematizada pelo ser humano. Circunscrever-se a isso não é sinônimo de negação ou de afirmação da verdade desse objeto, mas é um modo de delimitar o campo de abordagem da fenomenologia para um âmbito alcançável pelo discurso científico e para diferenciá-la da teologia.

Para além dessas fronteiras do que se estuda no fenômeno religioso, outra preocupação é o estabelecimento das diferenças sobre os modos como a teologia e a fenomenologia lidam com a religião. Nesse caso, há o cuidado por parte da fenomenologia em não incorrer em reducionismos teológicos. Se de um lado a fenomenologia busca evitar o reducionismo da religião a outras esferas sociais, ela também busca se precaver no sentido de preservar a autonomia dos dados religiosos em relação à redução a princípios teológicos. Neste caso, eles podem perder sua autonomia por serem submetidos a algum juízo que adota como critério uma determinada religião, tida como expressão última da verdade. Portanto, não deixa de ser um tipo de reducionismo.

O alerta para que se evite esse tipo de reducionismo aparece claramente na tradição fenomenológica holandesa (CHANTEPIE, 1891, p. 9; KRISTENSEN, 1960, p. 10; LEEUW, 1963, p. 645; 687; 104; 159; BLEEKER, 1954). Dada sua evidência, gostaria de me concentrar em outro caso mais complexo. Trata-se da proposta de Nathan Söderblom. Ele colocava para si dupla tarefa no estudo da religião: abordagem acurada das tradições religiosas e, de outro lado, interpretação teológica desses dados. Essa duplicidade torna essa diferenciação um pouco mais obscura, afinal, ao mesmo tempo em que assume essas duas incumbências, 
Söderblom faz questão de diferenciar os campos. Nas suas Gifford Lectures, de 1930/31, ele afirma:

A diferença entre pesquisa sobre religião em geral e teologia cristã em particular consiste no fato de que a crença na revelação é uma parte essencial desta última. Para a teologia cristã, a história das religiões é uma autocomunicação divina. O estudo comparado das religiões em geral deixa a questão sobre a revelação em aberto. Aquele que a pratica deve ser inspirado pela convicção que uma realidade supranatural está por detrás dos fenômenos da religião. Ou ele pode negar a crença no espiritual, a qual é fundamental para a religião. Ou ele pode permanecer indagando e incerto sobre a revelação, certo somente da impossibilidade de saber algo sobre ela. Ou ele pode não ter interesse na questão sobre a verdade da religião. Diferentes visões relacionadas à ideia de revelação podem, é claro, não influenciar o método de pesquisa e as investigações históricas e psicológicas de tal modo que eles são deslocados em uma direção ou pelo dogmatismo. O remédio contra esses erros não é proibir o pesquisador de ter certas convicções, mas somente de conduzir a investigação corretamente, conscientemente e seriamente, e submetendo-se prontamente às verdades percebidas. (SÖDERBLOM, 1933, p. 384).

Essa afirmação de Söderblom é importante por trazer uma ponderação consistente de como ele concebia essa relação entre Religião comparada (fenomenologia?)9 e teologia. Por vezes, para evidenciar o caráter teológico de sua concepção, menciona-se a história de que, no seu leito de morte, ele teria dito que poderia provar a existência de Deus por meio da história da religião (USARSKI, 2006, p. 40). Pela citação acima, percebem-se algumas possibilidades de articulação entre religião comparada e teologia que parecem ser mais complexas do que esse relato episódico e ocasional do seu leito de morte. A pedra de toque que diferencia as duas empreitadas é tomar uma revelação como normativa. A partir disso, o teólogo considera a história da religião não apenas como mera sucessão de fatos, mas como modo de manifestação de Deus. Aliás, o estudo da religião teria interesse para o teólogo justamente nesse aspecto, de lhe fornecer um quadro mais abrangente desse desenvolvimento histórico das religiões para que ele possa compreender melhor a estrutura teológica que organiza esse devir histórico. No entanto, para o estudo comparado das religiões abrem-se diversas possibilidades.

\footnotetext{
${ }^{9}$ Cabe lembrar que Söderblom, até onde pude levantar, não empregou o termo fenomenologia para caracterizar sua produção acadêmica. Como se vê pela citação, fala-se em estudo comparado das religiões. Isso levou a alguns intérpretes (SHARPE, 1986, p. 159) a aproximarem sua produção com a fenomenológica. Em geral, nas críticas à fenomenologia ele é citado como exemplar desse viés teológico da fenomenologia.
} 
Numa ponta, há aquela que se aproxima e se confunde com a teologia e acredita numa realidade transcendente por detrás da história até a postura que se situa no outro lado: o não interesse pela verdade da religião. É importante ressaltar que Söderblom escreve esse texto no início do século XX. Pelos desenvolvimentos posteriores, principalmente por meio da noção de epoché ou agnosticismo metodológico, firmou-se na fenomenologia essa ideia de que a verdade do objeto não se constitui objeto de análise da ciência da religião.

Mas, Söderblom também se ocupa com uma interpretação teológica desses dados, uma vez que história é autorrevelação de Deus. Portanto, não poderia haver real conflito entre a modernidade (inclusive, a ciência) e a revelação. Mas, é curioso que, na sua perspectiva sobre o estudo histórico das religiões, ao invés de se buscar por aquilo que elas tinham em comum, dever-se-ia ressaltar o específico de cada tradição religiosa. Enquanto teólogo entendia que somente com a história das religiões, o que implica em interpretar as manifestações religiosas em seus próprios termos, que se poderia dizer que o cristianismo seria a resposta para as necessidades humanas. Não se trata de assumir de princípio o cristianismo como resposta, mas de alcançar esse fim por meio do estudo da história das religiões. Por essa razão, ao invés de serem sinônimas de falsidade ou superstição, as religiões indicavam necessidades humanas. Neste caso, é bastante claro que ele ultrapassa a fronteira do estudo da religião para retirar conclusões teológicas. Mas, para nós, interessa como, pelo menos no plano teórico, há a preocupação de se distinguir quando se interpreta esses dados do ponto de vista do estudo da religião e quando eles são abordados a partir de motivações teológicas ${ }^{10}$. Para nossa discussão, a abordagem de Söderblom é indicativa que mesmo em projetos com motivações claramente teológicas, há certo cuidado de distinguir as competências da fenomenologia e da teologia.

\footnotetext{
${ }^{10}$ Sobre ele, Sharpe (1986, p. 159) emite o seguinte parecer: “A contribuição distintiva de Söderblom para a religião comparada talvez seja vista na atitude com a qual ele abordou seu material: levar a sério todas as religiões, não apenas como objetos de estudo científico, mas como religiões. Seus predecessores suecos e muitos de seus contemporâneos suecos tinham sido mais inclinados a tratá-las do ponto de vista da teologia dogmática cristã, como antirreligiões ou falsas religiões; e muitos de seus contemporâneos no campo do estudo da religião tenderam, explícita ou implicitamente, a considerá-las como curiosidades exóticas. Em sua preocupação pelo caráter sui generis, não apenas da religião como tal, mas também das religiões separadas, ele antecipou a atitude que hoje conhecemos como a abordagem fenomenológica".
} 
Aliás, justamente no sentido de se evitar qualquer confusão entre teologia e fenomenologia que certos autores defendem que o estudo da religião não dever ter qualquer finalidade prática. Bleeker é bastante incisivo na afirmação de que estamos diante de questão puramente acadêmica. Nas suas palavras, "Deve-se estudar os fenômenos religiosos criticamente, de forma imparcial, de maneira acadêmica e, ao mesmo tempo, com empatia" (BLEEKER, 1979, p. 176). Empatia e objetividade não são mutuamente excludentes, mas são requisitos para a interpretação da religião. Mas, o receio de que agendas teológicas determinem o estudo da religião acaba fazendo com que se levantem desconfianças com relação a qualquer tipo de aplicação prática da fenomenologia, que deve ser desinteressada desde seu método aos seus objetivos. Essa "contaminação" pode ocorrer quando interesses religiosos explícitos determinam o estudo da religião ou mesmo quando esses interesses, transvestidos de valores humanistas, são contrabandeados para a fenomenologia, mesmo que soem nobres, como a promoção do diálogo interreligioso.

Por fim, cabem ainda algumas palavras sobre aspecto teológico que poderia ser encontrado nas referências que se faz à dimensão religiosa do pesquisador. Alguns desses autores dizem que o pesquisador emprega sua própria experiência religiosa no sentido de entender a experiência religiosa do outro (KRISTENSEN, 1960, p. 163-164). No caso de van der Leeuw, enfatiza-se que a compreensão do outro se dá sempre com base em analogias com as referências religiosas que são mais próximas para o fenomenólogo. Mas, talvez aqui se esteja um problema. Uma vez que se interpreta a religião do outro partindo de referências religiosas do pesquisador, não se corre o risco (não digo que isso ocorre necessariamente, mas há um risco!) de promover uma compreensão teológica sob o manto da fenomenologia? Mas, há pelo menos dois aspectos a serem considerados aqui.

A própria International Association of History of Religions (IAHR) foi levada a repensar sua postura a partir de eventos realizados em países orientais, principalmente no Japão. O contato com outras formas de se pensar ciência levou a um questionamento: não se estabeleceu um vínculo muito rápido entre a noção 
moderna de ciência e o ideal de neutralidade e objetividade? A ciência moderna também não pressupõe uma compreensão filosófica de ser humano, mundo, conhecimento etc. tão situada e interessada como qualquer outra perspectiva? Não seria ela também um ponto de vista, uma forma tão localizada e válida como outras, da construção do conhecimento e respostas a problemas de determinados contextos históricos? A ciência moderna reconhece a indução como forma privilegiada de conhecimento. Mas, há outros possíveis. É célebre o caso de D.M. Datta, que no livro The Six Ways of knowing: a Critical Study of the Advaita Theory of Knwoledge (1960, publicado originalmente em 1932), ao fazer um estudo sobre a epistemologia vedanta, apresenta seis pramanas: percepção, comparação, conhecimento negativo, inferência, postulação e autoridade. Dessa maneira, tendo em vista a abordagem da religião, como defender um modelo que é tão situado quanto os outros como neutro e, ao mesmo tempo, lidar com a riqueza dessa pluralidade epistemológica proposta pelo pensamento religioso? E se ele, o nativo, aponta para outras formas de conhecimento que extrapolam esse modelo postulado pela ciência moderna?

O imbróglio, que não pretendemos resolver aqui, torna-se ainda maior ao se notar as consequências desse modo de percepção. Nesse caso, ao se considerar a contribuição do pensamento religioso, ainda se está fazendo fenomenologia da religião ou já se está no âmbito da teologia? Se a fenomenologia da religião surge enfatizando sua distinção da teologia, como, então, considerar a riqueza do objeto religião sem, no entanto, negar sua vocação científica? Enfim. A questão do compromisso de determinada abordagem com uma visão de mundo me parece ser bastante mais complexa do que afirmar uma pura neutralidade (como pretendem alguns fenomenólogos) ou de se acusar uma abordagem de criptoteologia (como pretendem seus críticos). Além disso, as teorias decoloniais vêm insistindo na quebra desse vínculo natural entre conhecimento objetivo e ciência moderna. Por ora, ainda sequer começamos a vislumbrar as consequências disso para a Ciência da Religião. Mas, para nossa discussão, fica o questionamento de se estabelecer essa correlação imediata entre objetividade e neutralidade com ideais científicos 
modernos e ocidentais. Por isso mesmo, é importante considerar a dimensão hermenêutica dessa discussão.

Gerard van der Leeuw ressalta o compromisso de não se emitir juízos dogmáticos. No entanto, uma vez que nos movemos num horizonte hermenêutico que nos fornece categorias a partir de onde interpretarmos as coisas, é consequência que aspectos da tradição religiosa que constituem esse horizonte também forneçam elementos conceituais para interpretar as demais. Mesmo quem não pensa a partir categorias com vínculos explícitos com a religião, acaba interpretando a partir de determinadas categorias igualmente situadas e mais próximas de sua vivência. As categorias sociológicas, por exemplo, surgem no final do século XIX como resposta às reconfigurações da sociedade industrial europeia. Portanto, elas também são situadas. Inclusive, coerente com isso, van der Leeuw assume ao final da sua obra que outras fenomenologias, partindo de outras perspectivas, deveriam ser escritas (LEEUW, 1963, p. 646).

A outra dimensão desse aspecto é o impacto do objeto sobre o estudioso. Leeuw reconhece que é "totalmente impossível contemplativamente confrontar um evento que, de um lado, é uma experiência última, e de outro se manifesta em profunda agitação emocional, na atitude de pura contenção intelectual" (LEEUW, 1963, p. 683, cf; p. 645). Em outros termos, ele admite que ao lidar com a esfuziante dimensão religiosa não é possível postura de plena indiferença. Mais recentemente, Ninian Smart reconhece que haveria espaço no estudo da religião para uma dimensão de espiritualidade do pesquisador. Ao tratar de maneira concisa sobre os contornos do moderno estudo da religião, aceita que a pesquisa acadêmica "pode ser o cenário não apenas para uma compreensão letrada do mundo e seus vários sistemas de crença, mas também para uma pergunta pessoal pela verdade espiritual" (SMART, 1983, p. 22).

Enfim, em virtude disso, podemos afirmar que a fenomenologia é uma espécie de exercício religioso ou teologia? Esse juízo depende muito do peso que se confere ao papel que esses aspectos exercem na abordagem fenomenológica. Mas, a 
meu ver, esses autores não estão defendendo que a finalidade última do estudo fenomenológico da religião é o desenvolvimento da espiritualidade do pesquisador ou coisa do tipo. No entanto, eles reconhecem que o pesquisador não é um ser isento, que observa a religião de um ponto de vista puramente intelectivo, como se fosse somente cérebro. Ele também é afetado no que concerne à temática religiosa, que pode gerar tanto admiração como certa repulsa. Aliás, essa percepção de que o pesquisador é afetado por aquilo que estuda é cada vez mais compartilhada por muitos antropólogos contemporâneos, inclusive no que concerne à temática religiosa (FAVRET-SAADA, 2005; MARQUES, 2009). Portanto, não vejo que, ao assumir essa relação com o objeto se esteja necessariamente incorrendo numa posição teológica.

\section{Conclusão}

Ainda, enquanto aluno do curso de filosofia, uma vez ouvi uma frase que marcou muito meu processo formativo. O professor, em meio a uma aula, disse: “em filosofia não existem autores superados". Acho que a regra vale também para outros campos do saber. Uma vez que o conhecimento em ciências humanas é um saber cumulativo, diferentemente de áreas técnicas, um autor ou escola não podem simplesmente serem considerados superados porque surgiram teorias mais recentes. Descartar uma abordagem por não ser mais útil ou por simplesmente não atender às tendências da última moda representa, para as ciências humanas, um empobrecimento e um perigo. Empobrecimento porque elas são muito dependentes de uma tradição de autores que sempre se mostram instigantes interlocutores. Perigo por se perder em tendências positivistas, como se o valor das ciências humanas pudesse ser reduzido à aplicação prática imediata.

A fenomenologia é passível de crítica? Claro. Há vários problemas e lacunas nas propostas fenomenológicas. Aliás, seus principais autores reconhecem que ela nunca é definitiva e precisa ser incessantemente revisitada. Trata-se de um projeto inacabado. Mas, para uma crítica bem sustentada não se pode ignorar sua complexidade interna. 
É nesse sentido que a abordagem que propus do tema da fenomenologia da religião nesse artigo deve ser entendida. Como mencionado em seu início, não se trata de uma defesa da fenomenologia da religião. Por outro lado, incomoda-me posturas que defendem seu descarte com base no pressuposto de que se trata de uma escola superada, pautando-se na autoridade de escritores ou contextos distintos do brasileiro, como se a mera acusação de essencialismo e criptoteologia fosse suficiente para a sentença de morte dessa escola. Muitas vezes, os argumentos são muito rápidos e não dão direito de fala a quem está sendo julgado. Muitas vezes, para que a sentença já foi dada antes da análise. Pelo que espero ter demonstrado com o artigo, essas questões são muito mais complexas que o tom acusatório permite perceber. Posturas como essas trazem como prejuízo a ausência de discussão sobre os argumentos como tematizados pelos próprios autores. Esse aspecto é, sobretudo, importante no contexto brasileiro, no qual há clara lacuna de conhecimento e leitura de autores clássicos da Ciência da Religião.

Quando se trata de clássicos, esse é um ponto sensível. Não se lê um texto ou autor clássico para repeti-lo ou simplesmente para aplicá-lo a um estudo de caso, mas, muitas vezes, para se levantar questões importantes e reconhecer limites de certas abordagens e identificar onde estão os pontos complexos. Uma das razões pelas quais meu antigo professor dizia que era importante não nos esquecermos que não há autores "superados" na filosofia era para que não precisássemos reinventar a roda a todo o momento, propondo-se ideias com ar de novidade, sem reconhecer o lastro de outros que já pensaram questões semelhantes. Nesse sentido, é curioso que muitas vezes nos deparemos com propostas de articulação da Ciência da Religião que aparentemente se mostram críticas da fenomenologia, mas acabam incorporando muitas de suas ideias e pressupostos. Afinal, pela abordagem aqui empreendida, é fácil identificar a defesa de uma postura de objetividade por parte da fenomenologia. Além disso, o agnosticismo metodológico leva à recusa de se fazer perguntas pela verdade última do objeto da religião, assim como o julgamento, inclusive a partir de critérios religiosos. Enfim. Não temos aqui elementos que muitos consideram como sendo constituintes da Ciência da Religião? 


\section{REFERÊNCIAS}

BLEEKER, C. J. Evaluation of previous methods: Commentary. In: HONKO, L. (ed.).

Science of Religion. Studies in methodology. Proceedings of the study conference of the International Association for the History of Religions, held in Turku, Finland, August 27-31 1973. The Hague; Paris; New York: Mouton Publishers, 1979. p. 173-174.

BLEEKER, C. J. The rainbow. A collection of studies in the Science of Religion. Leiden: E. J. Brill, 1975 .

BLEEKER, C. J. The relation of the History of Religions to kindred Religious Sciences, particularly Theology, Sociology of Religion, Psychology of Religion and Phenomenology of Religion. Numen, v. 1, p. 141-155, 1954.

BLEEKER, C. J. The sacred bridge. Leiden: E.J. Brill, 1963.

CAMURÇA, Marcelo. Les Sciences Religieuses: um olhar a partir do Brasil para o campo de estudo das ciências da religião na França. Estudos de Religião, São Bernardo do Campo, v. 25, n. 41, p. 12-28, 2011. Disponível em: https://www.metodista.br/revistas/revistasims/index.php/ER/article/view/2809. Acesso em: 12 set. 2019.

CAPPS, Walter. Religious Studies. The making of a discipline. Minneapolis: Fortress Press, 1995.

CARMAN, John B. Modern understanding of ancient insight: distinctive contributions of W. B. Kristensen's Phenomenology of Religion. In: HJELDE, Sigurd. Man, meaning, and mystery. 100 years of History of Religions in Norway. The heritage of W. Brede Kristensen. Leiden: Brill, 2000. p. 157-172.

CHANTEPIE DE LA SAUSSAYE, P. D. Manual of the Science of Religion. Londres: Longmans, Green, and Co., 1891.

COX, James. A guide to the Phenomenology of Religion. New York: The Continuum International Publishing Group, 2006.

DATTA, D. M. The six ways of knwoing: a critical study of the advaita theory of Knwoledge. 2nd ed. Calcutta: University of Calcutta, 1960.

ELIADE, Mircea. O sagrado e o profano. São Paulo: Martins Fontes, 1992.

ELIADE, Mircea. Tratado de história das religiões. São Paulo: Martins Fontes, 2008.

ENGLER, Steven. Teoria da religião norte-americana: alguns debates recentes. Rever, São Paulo, n. 4, p. 27-42, 2004. Disponível em:

https://www.pucsp.br/rever/rv4_2004/t_engler.htm. Acesso em: 12 set. 2019.

FAVRET-SAADA, Jeanne. Ser afetado. Cadernos de Campo, São Paulo, n. 13, jan./dez., p. $155-161,2005$. 
FITZGERALD, Timothy. The ideology of Religious Studies. Oxford, UK: Oxford University Press, 2000.

GASBARRO, Nicola. Fenomenologia da religião. In: PASSOS, João D; USARSKI, F. (org.). Compêndio de Ciência da Religião. São Paulo: Paulinas, 2013. p. 51-62.

GRESCHAT, Hans-Jürgen. O que é Ciência da Religião? São Paulo: Paulinas, 2006.

HEILER, Friedrich. La historia de las religiones como preparcion para la cooperacion entre las religiones. In: ELIADE, M; KITAGAWA, J. Metodología de la historia de las religiones. Barcelona: Paidos, 1996. p. 167-199.

INDINOPULOS, Thomas; YONAN, Edward. Religion and reductionism. Essays on Eliade, Segal, and the Challenge of the Social Sciences for the Study of Religion. Leiden: E. J. Brill, 1994.

JAMES, George Alfred. Interpreting religion. The phenomenological approaches of Pierre Daniel Chantepie de la Saussaye, W. Brede Kristensen, and Gerardus van der Leeuw. Washington: The Catholic University of America Press, 1995.

KRISTENSEN, W.B. The meaning of religion. The Hague: Martinus Nijhoff, 1960.

LEEUW, Gerard van der. Religion in essence and manifestation. New York: Harper \& Row, 1963.

LEWIS, Thomas. Why philosophy matters for the Study of Religion \& vice versa. Oxford: Oxford University Press, 2015.

MARQUES, Delcides. Confissões e ficções de um antropólogo: etnografia dos pregadores da Praça da Sé. Dissertação (Mestrado em Antropologia Social) - Universidade Estadual de Campinas, Campinas, 2009.

McCUTCHEON, Russell. Critics not caretakers: redescribing the public Study of Religion. Albany, NY: SUNY Press, 2001.

MOLENDIJK, Arie L. At the cross-roads: early dutch Science of Religion in international perspective. In: HJELDE, Sigurd. Man, meaning, and mystery. 100 years of History of Religions in Norway. The heritage of W. Brede Kristensen. Leiden: Brill, 2000. p. 19-55.

MÜLLER, F. M. Introduction to the Science of Religion. London: Longmans, 1893.

OXTOBY, Williard. Religionswissenschaft Revisited. In: NEUSNER, Jacob (ed.).

Religions in antiquity: essays in memory of Erwin Ramsdell Goodenough. Leiden: E. J. Brill, 1968. p. 590-608.

PALS, Daniel L. Is Religion a Sui Generis Phenomenon? Journal of the American Academy of Religion, v. 55, n. 2, p. 259-284, 1987.

PENNER, Hans. Is Phenomenology a method for the Study of Religion? Bucknell

Review, v. 18, n. 1, p. 29-54, 1970. 
PIEPER, F. A especificidade e autonomia da religião em R. Otto. In: SANTOS, Joe; HUFF JÚNIOR, Arnaldo. De Lutero a Otto. O protestantismo e a ciência da religião. São Cristóvão: Editora da Universidade Federal de Sergipe, 2018. p. 131-152. Disponível em: http://www.livraria.ufs.br/produto/de-lutero-a-otto-o-protestantismo-e-a-ciencia-dareligiao/. Acesso em: 12 set. 2019.

PIEPER, F. Religião: limites e horizontes de um conceito. Estudos de Religião, v. 33, n. 1, p. 5-35, 2019. Disponível em: https://www.metodista.br/revistas/revistasims/index.php/ER/article/view/9056. Acesso em: 12 set. 2019.

SHARPE, E. Comparative Religion: a history. 2. ed. London: Duckworth, 1986.

SHARPE, E. The Phenomenlogy of Religion. Learning for Livinng, v. 15, n. 1, 1975.

SILVEIRA, Emerson Sena da. Uma metodologia para as ciências da religião? Impasses metodológicos e novas possibilidades hermenêuticas. Paralellus, v. 7, n. 14, p. 73-98, 2016. Disponível em: http://www.unicap.br/ojs/index.php/paralellus/article/view/672. Acesso em: 12 set. 2019

SMART, Ninian. The phenomenon of religion. New York: The Seabury Press, 1973.

SMART, Ninian. Wolrdviews crosscultural, explorations of human beliefs. New York: Carls Scribner's Sons, 1983.

SÖDERBLOM, N. The living God. Basal forms of personal religion. London: H. Milford and Oxford University Press, 1933.

TIELE, C. P. Elements of the Science of Religion. London: William Blackwood and Sons, 1897. v. 1.

USARSKI, Frank. Constituintes da ciência da Religião. São Paulo: Paulinas, 2006.

WAARDENBURG, Jacques. Progress in research on meanings in religions (1898-1998). In: HJELDE, Sigurd. Man, meaning, and mystery. 100 years of History of Religions in Norway. The heritage of W. Brede Kristensen. Leiden: Brill, 2000. p. 255-285.

WACH, J. Introduction to the History of Religions. New York: MacMillan Publishing Company, 1988.

WIEBE, Donald. Religião e verdade: rumo a um paradigma alternativo para o estudo da religião. São Leopoldo: Sinodal, 1998.

WINDEGREN, Geo. Fenomenológía de la religión. Tradução de Álvaro Alemany. Madrid: Ediciones Cristiandad, 1969. 